logos_i_ethos_2020_1_(53), s. 209-230

DOI: http://dx.doi.org/10.15633/lie.3697

Jacek Breczko

http://orcid.org/0000-0002-8862-9721

Uniwersytet Medyczny w Białymstoku

\title{
Hasło sprawiedliwości społecznej jako wstęp do tyranii
}

Terror bez cnoty jest zgubny, cnota bez terroru jest bezsilna.

Robespierre

Rewolucyjny terroryzm jest nie tylko niezawodnym i najpraktyczniejszym sposobem dezorganizacji istniejącego policyjno-biurokratycznego państwa, ale także jedynym skutecznym środkiem przeobrażenia niewolniczo poddanych sług w ludzi - obywateli

Piotr Tkaczow

Wprowadzenie. Klasyczne rozumienia - Platon

\section{i Arystoteles}

Hasło sprawiedliwości społecznej bywało różnie rozumiane i różnie w życie wprowadzane. Było podstawą przemian - w szerokim sensie tego słowa - demokratycznych, bywało też propagandowym „chwytem” oraz wstępem do tyranii. Platon bodaj pierwszy dostrzegł, że demokracja - kiedy wątek „redystrybucji dóbr” w imię egalitaryzmu
Jacek Breczko - dr hab., pracownik Studium Filozofii i Psychologii UMB. Zainteresowania naukowe: historia idei, historiozofia, filozofia polityki, etyka. Ważniejsze publikacje: Poglady historiozoficzne pisarzy z kregu „Kultury" paryskiej. Przezwyciężenia katastrofizmu, odrzucenie mesjanizmu, Lublin 2010; Cywilizacja na zakręcie. Szkice $z$ historii filozofii i filozofii historii, Lublin 2014; O empatii, empatycznej cywilizacji i nowej duchowości, Białystok 2019. 
(zrównania różnic majątkowych) wychodzi na plan pierwszy - niejako „spontanicznie” zamienia się w tyranię.

Zacznijmy przeto od klasycznego schematu Platona, zawartego w ósmej księdze Państwa, gdzie pokazuje, jak ustroje ewoluują i zarazem się degenerują; przechodzą stopniowo od najlepszego do najgorszego: od arystokracji, przez timokrację, oligarchię, do demokracji, a następnie do tyranii. To ostatnie przejście - od nieograniczonej wolności do zupełnego zniewolenia - jest szczególnie interesujące i na nim się tu skoncentrujemy. Należy jednak zaznaczyć, że demokracja, o jakiej pisze Platon, to nie współczesna konstytucyjna demokracja liberalna $\mathrm{z}$ podziałem władz, ale bezpośrednie „ludowładztwo” ateńskie.

Barwny i wyrafinowany literacko dialog Platona spróbuję sprowadzić do telegraficznie ujętej sekwencji zdarzeń. Modelowa historia opisana przez filozofa wygląda mniej więcej tak.

W demokratycznej społeczności można wyróżnić trzy grupy: 1) bogaczy („kiedy wszyscy robią pieniądze, najporządniejsi z natury często się wzbogacają najbardziej”), 2) lud pracujący oraz - uwaga - 3) „próżniaków i rozrzutników”, tj. cwaniaków, unikających pracy, kochających luksus i zabawy - Platon nazywa ich trutniami. Ci ostatni występują w różnych ustrojach; w demokracji wszakże - gdzie panuje wolność i każdy może robić, co mu się podoba - jest ich najwięcej i oni to przede wszystkim garną się do polityki. „Ten żywioł... przemawia i działa... obsiada mównice naokoło, i robi hałas i szum, i nie daje do słowa dojść nikomu, kto by mówił inaczej”" Trutnie opanowują więc agorę i z nich - najbardziej odważnych, bezczelnych i bystrych - wywodzi się (w znacznej mierze) demokratyczna klasa polityczna. Kolejny krok: trutnie schlebiają ludowi pracującemu, który jest najliczniejszy (ma przeto „największy wpływ w demokracji, kiedy się schodzi na zgromadzenia”). W jaki sposób? Otóż „oni zabierają tym, którzy mają majątek, dzielą między lud, a najwięcej zachowują dla siebie"2. Bogacze stają się - powiada Platon - „paszą trutni”. W ten sposób

1 Platon, Państwo, tłum. W. Witwicki, t. 1, Warszawa 1958, s. 449.

2 Platon, Państwo, dz. cyt., s. 450. 
popularność trutni wśród ludu rośnie, a zwłaszcza trutnia „najostrzejszego” („lud zawsze zwykł kogoś jednego szczególniej wysoko wynosić i stawiać na swoim czele; żywi go i pomaga mu do wzrostu"3).

Antagonizm między bogaczami i ludem narasta, sprytnie podsycany przez trutnie. Pozbawiani majątku bogacze próbują - rzecz jasna - się bronić. Najpierw legalnie, przemawiając na agorze i zakładając sprawy w sądach; trutnie ich jednak zakrzykują, a ludowe sądy skargi odrzucają; następnie nielegalnie, spiskując przeciwko demokracji. Przywódca trutni i zarazem - coraz bardziej wybijający się na czoło - trybun ludowy czuje się zagrożony i prosi lud o przyznanie ochronnej gwardii. Lud - „bojąc się o niego i nie bojąc się o siebie" - taką gwardię mu przyznaje. Nic dziwnego zresztą; ów przywódca „w pierwszych dniach i czasach... będzie się uśmiechał do wszystkich i każdego uprzejmie witał, kogo tylko spotka i będzie mówił nawet, że nie jest dyktatorem, a będzie przyrzekał wiele iprywatnie,ipublicznie, będzie długi skreślał i ziemię rozdzielał ludowi i swoim najbliższym, i... będzie udawał łagodnego i łaskawego dla wszystkich"4.

Fałszywie jednak oskarżając i doprowadzając do skazywania na śmierć lub wygnanie niewinnych, przekracza pewną granicę. Ma krew na rękach i nie może już się cofnąć ( $\mathrm{z}$ trutnia zamienia się - jak sugeruje Platon - w wilka gnanego instynktem samozachowawczym i coraz bardziej żądnego ludzkiej krwi).

Dotąd łupi bogaczy, aż źródło wysycha (część bowiem ucieka, część zostaje skazana na śmierć, inni bankrutują). I wtedy zaczyna konfiskować majątek świątynny - jedyny wielki, jaki zostaje w państwie - dzieląc go między lud, a najwięcej zachowując dla siebie i swojej gwardii. Wszczyna też wojny zewnętrzne, co pozwala mu - jako wodzowi na czas wojny - konsolidować władzę. Odważni i roztropni obywatele, którzy widzą, że sprawy idą w złym kierunku, sprzeciwiają się i protestują. Robi więc „czystkę szlachetnych”. Odtąd otacza się już tylko miernotami i pochlebcami. Wzmacnia też swoją gwardię; zatrudnia najemników

3 Platon, Państwo, dz. cyt., s. 451.

4 Platon, Państwo, dz. cyt., s. 453. 
(cudzoziemców) oraz wyzwala niektórych niewolników i zamienia w gwardzistów (są mu przeto ślepo posłuszni). Liczna gwardia potrzebuje wszakże dużego żołdu. Bogacze zostali złupieni, majątek świątynny skonfiskowany; kto zatem pozostaje? Lud!

Mający mało, ale - kiedy przemnoży się „mało” przez dużą liczbę jednak coś. Trybun ludowy zaczyna przeto łupić lud, aby utrzymać gwardię - gwarancję swojego bezpieczeństwa. Lud się buntuje, ale liczna i wierna gwardia krwawo bunt poskramia. W ten oto sposób przywódca ludu staje się tyranem. Syn ludu zamienia się - powiada Platon - w ojcobójcę. Lud zaś - odrzucający wcześniej jakiekolwiek arystokratyczne ograniczenia, prawa i miary (będący przez chwilę „miarą wszechrzeczy”) - zamienia się w „niewolnika niewolników”. W ten sposób Platon kończy tę opowieść.

Ujmując rzecz możliwie najkrócej: w demokracji „populiści”, krzykacze, próżniacy i rozrzutnicy - udając „przyjaciół ludu” i posługując się "transferami socjalnymi” - zdobywają pełnię władzy, likwidują demokrację i wprowadzają tyranię, czyli bezprawne rządy oparte na przemocy, okrucieństwie, strachu i terrorze.

Platon przepisuje przeto lekarstwo: państwo doskonałe, arystokrację filozoficzną posiadającą liczne cechy ustroju Sparty (lekarstwo to jednak okazało się toksyczną trucizną ${ }^{5}$ ). Pod koniec życia, w Prawach, szuka rozwiązania kompromisowego i w większym stopniu opartego na doświadczeniu historycznym (zwycięstwo Sparty w wojnie peloponeskiej to wszak tylko mały wycinek historii). Pomysł ten można streścić jako zarazem rządy prawa oraz ustrój mieszany; monarchiczno-demokratyczny. Mądry król stanowi sprawiedliwe prawa, ale nie narzuca ich ludowi, przekonuje do nich lud. Nie jest jak lekarz, który narzuca terapię pacjentowi, bo wie lepiej, ale przekonuje pacjenta do terapii, uzyskuje jego świadomą zgodę. A przeto pacjent (lud) włącza się w kurację dobrowolnie i współpracuje z lekarzem (monarchą). Tym też tropem podąża Arystoteles, inaczej jednak rozkłada akcenty.

5 Rzec więc można, że Platon był lepszym diagnostą niż projektantem i wizjonerem. 
Wydaje się, że Arystoteles - w swojej filozofii politycznej - próbuje wybrnąć z pułapek, które dostrzegł Platon, analizując ewolucję ustrojów ( $z$ jednej strony oligarchiczny ucisk ubogich przez bogaczy, $z$ drugiej strony grabienie bogaczy, w imię ludu, w demokracji). Proponuje więc podobnie jak stary Platon - rozwiązanie kompromisowe, ustrój mieszany. Twierdzi, że najlepszym ustrojem jest monarchia (rządy jednego), ale ona łatwo przeradza się w tyranię; innym dobrym ustrojem - choć nieco gorszym - jest arystokracja (rządy nielicznych i najlepszych), ale ona również łatwo przeradza się we władzę bogaczy (oligarchię). Najmniej dobrym $\mathrm{z}$ dobrych ustrojów jest politeja. I tu zaskoczenie: to zdrowa mieszanka dwóch ustrojów niezdrowych: oligarchii i demokracji. Ten ustrój ma też dodatkową zaletę; kiedy głęboko zapuści korzenie, okazuje się trwały, mało wywrotny oraz rodzący - niezwykle cenną w państwie klasę średnią. Na czym opiera się owa trwałość i owocność? Na umiarze i kompromisie. Politeja to bowiem albo rządy bogaczy, którzy dbają o lud, albo rządy ludu, który dba o bogaczy (a nie ich łupi i prześladuje).

\section{Wielka Rewolucja Francuska}

Platon opisywał procesy polityczne w małych społecznościach (polis), warto rozważyć, czy jego schemat „sprawdzał się" w przypadku wielkich społeczności nowożytnych. Szukając - prowizorycznej, siłą rzeczy - odpowiedzi na to pytanie, chciałbym się skoncentrować na dwóch wyrazistych przypadkach: Wielkiej Rewolucji Francuskiej i rewolucji rosyjskiej. Obydwie wszak zaczynają od radykalnego ludowładztwa, a kończą na rewolucyjnym terrorze.

Zacznijmy od rewolucji francuskiej. Najpierw wolnościowa i umiarkowana (przeciwko monarszemu absolutyzmowi, ale nie przeciwko monarchii, która miała zostać przekształcona w monarchię konstytucyjną); stawała się z czasem - zgodnie ze swoistą „logiką” rewolucyjnych wydarzeń - coraz bardziej radykalna, egalitarna i krwawa. Terminy „wolność" i „równość” splotły się ze sobą i wymieszały. Jeśli jednak przyjąć ich potoczny sens, rewolucja francuska ewoluowała od wolności do równości. 
Przez pierwsze trzy lata na czele władzy wykonawczej nadal stał przynajmniej formalnie - król; władzę ustawodawczą sprawowała najpierw Konstytuanta, a następnie zaś Legislatywa (gdzie przeważały raczej „żywioły umiarkowane”). Natomiast nastroje społeczne wśród ludu, a szczególnie miejskiej biedoty, się radykalizowały; domagano się prawdziwej równości, pełnej demokracji oraz wprowadzenia republiki; na zebraniach politycznych zaczęła dominować forma grzecznościowa „obywatel” (a nie „pan”). Coraz bardziej wpływowi byli kordelierzy i jakobini mający oparcie w sankiulotach. W kraju panował bałagan, rozkręcała się inflacja, uderzająca w najbiedniejszych, co z kolei wzmacniało egalitarystyczny radykalizm. Wiosną 1792 roku wybucha wojna z Austrią i Prusami, dolewająca oliwy do ognia radykalizmu. Wypadki potoczyły się błyskawicznie; klęski na frontach przyczyniły się do wybuchu w sierpniu „drugiej rewolucji”, aresztowania króla, wprowadzenia powszechnego prawa głosowania. $\mathrm{W}$ tym czasie odwraca się sytuacja na frontach, Austriacy i Prusacy wycofują się z Francji, zajęci bardziej rozbiorem Polski.

Po kolejnych wyborach - tworzących trzeci parlament, tzw. Konwent - dominować zaczynają jakobini, mający oparcie w paryskich masach. Król zostaje skazany na śmierć, wyrok wykonano niezwłocznie, w styczniu 1793. Wywołuje to powszechne oburzenie w Europie; powstaje pierwsza wielka antyfrancuska koalicja (organizowana przez Wielką Brytanię), wybuchają też powstania chłopskie (największe w Wandei) oraz zamieszki - często "na tle głodowym” - w licznych miastach. Zagrożenie zewnętrze i wewnętrze skłania do konsolidacji władzy; jakobini decydują się na przeprowadzenie zamachu stanu; aresztowani zostają główni ich przeciwnicy w Konwencie i zaczyna się jakobińska dyktatura. Centrum władzy wykonawczej zostaje tzw. Komitet Ocalenia Publicznego, na którego czele staje najpierw Danton, a następnie Robespierre. Rewolucja francuska wkracza - w ten sposób - na nowe tory i ten okres szczególnie nas tu interesuje. W czerwcu zostaje uchwalona druga Konstytucja, zdecydowanie bardziej demokratyczna niż pierwsza, z powszechnym prawem wyborczym, powszechną darmową oświatą oraz pewnymi prawami socjalnymi. Wkrótce po uchwaleniu zostaje jednak 
zawieszona (okazuje się być w znaczniej mierze zabiegiem propagandowym). Obowiązują tymczasem środki nadzwyczajne, w skrócie terror rewolucyjny.

Uzasadnieniem dyktatury i terroru jest - między innymi - walka z nędzą wśród mas, czyli postulat równości i sprawiedliwości socjalnej i ekonomicznej. Stosuje się masowo rekwizycje. Zabiera się żywność chłopom, dostarcza do miast i w różny sposób rozdziela lub sprzedaje. Do wsi, które nie dostarczały wyznaczonego kontyngentu, wysyła się specjalnych agentów i dokonuje się aresztowań wśród mieszkańców, poczynając od przedstawicieli władz samorządowych. Wprowadza się uchwałę przeciw spekulantom, ceny maksymalne na zboże, ogólny cennik na żywność, kartki na mięso i chleb oraz przepisy o jakości chleba. Wolny rynek i pieniądz zastępuje - w znacznej mierze - przemoc stosowana w interesie ludu; z czarnym rynkiem i spekulacją walczy się za pomocą terroru.

Podkreślmy: władza używała środków nadzwyczajnych (rekwizycji, wszechobecnej kontroli oraz terroru), aby bronić ludu, bronić najuboższych. I lud (peuple, a nie nation) tę władzę popierał, pomagał jej „rosnąć” i wzmacniać organy przemocy. Pojawia się więc sprzężenie zwrotne, w którym cel i środek wzajem się zamieniają i wzmacniają. I trudno odróżnić, co jest w hierarchii wyżej, a co niżej, co w istocie jest celem, a co środkiem. Czy, krótko mówiąc, centralizacja władzy jest środkiem do równości i pomocy najbiedniejszym, czy pomoc najbiedniejszym i hasło „równości” jest środkiem do centralizacji, a wreszcie wszechwładzy rewolucjonistów. Wydaje się, że im dalej rewolucja postępuje, tym bardziej prawdą staje się to drugie (wrócę do tego).

Na skrajnej lewicy, w otoczeniu Héberta (wśród tak zwanych „wściekłych”) pojawiają się postulaty eksterminacji bogaczy i podziału ich majątków między lud. „Jest rzeczą konieczną, by sierp wolności przeszedł po głowach bogaczy" - jak to poetycko ujął jeden z jego zwolenników. Robespierre - mimo że był wrażliwy na nastroje tłumu - nie poszedł tak daleko. Dystansował się z jednej strony od umiarkowanego Dantona (niechętnego utrzymywaniu cen maksymalnych, zniechęcających do produkcji i powodujących pustki w sklepach), z drugiej od owych 
komunizujących - i dodajmy „wściekle” antychrześcijańskich - radykałów (którzy byli jego głównymi oponentami w Komunie Paryskiej). Ostatecznie i skrzydło umiarkowane, i radykalne zostają odcięte: na gilotynę trafia najpierw Hébert, a następnie Danton.

Robespierre zostaje dyktatorem; wprowadza nową religię, kult Istoty Najwyższej (jako gorliwy czytelnik Rousseau, sądzi, że społeczeństwo bez religii istnieć nie może, „lud potrzebuje świąt”); utrzymuje rekwizycje i ceny maksymalne, i zaostrza terror (tzw. Wielki Terror).

I oto nagle - po kilku miesiącach pełni władzy - Robespierre przegrywa. Wolno domniemywać, że popełnił jeden błąd taktyczny i dwa strategiczne. Pierwszy polegał na tym, że przechodząc do kolejnej tury konsolidacji władzy, zapowiedział w Konwencie, że wkrótce ujawni nowy spisek, nie podał jednak nazwisk zdrajców, przez co wszyscy poczuli się zagrożeni. Zawiązali przeto w nocy faktyczny spisek i następnego dnia nie pozwolono mu już zabrać głosu i w ogólnym tumulcie przegłosowano jego aresztowanie. I mimo że tłum go uwolnił, Robespierre nie potrafił podjąć skutecznej kontrakcji; został ponownie aresztowany i po krótkim procesie - zgilotynowany.

Inny błąd, poważniejszy. Nie dość dbał o osobistą ochronę; powinien wystąpić do ludu (jak w schemacie Platona) o stworzenie specjalnej gwardii przybocznej, wyprowadzić się z nędznego pokoiku, który wynajmował u pewnego szewca i zamieszkać w jakiejś ściśle strzeżonej twierdzy. Po trzecie, skoro utrzymał rekwizycje, ceny maksymalne i zarazem zaostrzył terror, nie mógł liczyć na szlachtę i kler (to oczywiste), ale też nie mógł liczyć ani na chłopów, ani na zamożnych i średnio zamożnych mieszczan (przemysłowców, kupców, członków wolnych zawodów), ani nawet na drobnomieszczan; mógł się oprzeć tylko na coraz liczniejszej i coraz bardziej radykalnej biedocie w Paryżu i innych miastach. Powinien zatem przejąć program Héberta $\mathrm{i}$ - ponownie zgodnie ze schematem Platona - zdecydowanie uderzyć w bogaczy, konfiskując ich majątki, a za zdobyte środki rozszerzyć opiekę państwa i ustawodawstwo socjalne (w duchu Konstytucji 1793); wprowadzić darmowe rozdawnictwo ubrań, żywności, mieszkań (zasiedlając biedakami pałace i mieszczańskie kamienice). W kolejnym zaś kroku, zarazem wzmacniając rewolucyjną 
falę nienawiści do bogaczy i spekulantów oraz płynąc na niej, wyruszyć w kierunku, w którym potem próbował zmierzać Babeuf i jego Sprzysiężenie Równych, to znaczy zrobić kolejną „rewolucję w rewolucji”; zlikwidować pieniądze, znieść własność prywatną, ustanowić wspólnotę dóbr oraz - najważniejsze - równość w korzystaniu z nich („aby każdy miał dość, aby nikt nie miał za dużo"6). Uzasadnieniem zaś dyktatorskiej władzy i terroru uczynić właśnie strzeżenie owej równości.

Pozwolę sobie teraz wkroczyć na niepewny grunt historii alternatywnej. Otóż - gdyby tak postąpił - rządziłby dłużej; nie miesiące, a lata. Francja zaś wyszłaby zapewne z takiego eksperymentu ustrojowego zrujnowana, nie miałaby więc potencjału na „eksport rewolucji” i napoleońską epopeję. Co więcej, opłakane skutki eksperymentu komunistycznego w środku Europy u schyłku XVIII wieku (a trudno sądzić, że byłyby inne) zapobiegłby zapewne rozprzestrzenianiu się idei komunistycznej w XIX wieku; nie byłoby marksizmu, kolejnych międzynarodówek i wreszcie rewolucji komunistycznej w Rosji. Komunizm wprowadzany przez Robespierre’a zadziałałby niczym szczepionka.

Nie było to nierealne, wszak „duch komunizmu” unosił się wówczas nad Paryżem, uosabiany najpierw przez sankiulotów i hebertystów, a następnie przez Spartakusa Babeufa, Filippa Buonarrotiego oraz Sprzysiężenie Równych, które Karol Marks nazwał pierwszą komunistyczną partią w dziejach.

\section{Blanqui, Tkaczow, Lenin}

Stało się jednak inaczej. W XIX wieku niezwykle bogate spektrum utopii, teorii oraz politycznych ruchów egalitarystycznych było inspirowane „niedokończoną” rewolucją francuską; była natchnieniem, zapładniała wyobraźnię marzycieli, filozofów i działaczy politycznych (zwłaszcza kontynentalnych, w mniejszym stopniu angielskich). Szczególnie interesuje mnie tutaj najbardziej radykalna część owego spektrum;

6 P. Buonarroti, Sprzysiężenie równych, t. 1, tłum. A. Jeżewski, Warszawa 1952, s. 50. 
zwolennicy rewolucji i terroru oraz zniesienia własności prywatnej i wprowadzenia pełnej równości.

Najbardziej może wyraźna linia w tym gronie wiedzie od - wspomnianego już - Babeufa (który założył organizację konspiracyjną i próbował dokończyć - w czasach dyrektoriatu - rewolucję francuską w duchu roussoizmu i komunizmu) do innego konsekwentnego konspiratora i rewolucjonisty, wielokroć więzionego - Luisa Augusta Blanquiego, który „przekazał dziedzictwo babuwizmu... pokoleniu 1848 i późniejszym”7. Wśród rewolucjonistów rosyjskich - najbardziej bodaj radykalnych w Europie - dziedzictwo babuwizmu przejął zaś Piotr Tkaczow, a po nim Włodzimierz Lenin.

Blanqui przejął od Babeufa (i jego zwolenników) dwa poglądy: egalitarną rewolucję powinna przeprowadzić zakonspirowana elitarna organizacja; bezpośrednio zaś po rewolucji nie należy oddawać władzy ludowi; rządy powinni sprawować - dopóki lud nie osiągnie odpowiedniego poziomu świadomości - owi konspiratorzy.

Babeufa i Blanquiego łączy przekonanie, że lud jest chwiejny i niezbyt rozgarnięty (nie rozpoznaje jasno własnego interesu); nie można więc na nim polegać i nie warto przejmować się jego pragnieniami i dążeniami, które zazwyczaj sprowadzają się do haseł umiarkowanych, reformistycznych (większych zarobków, skrócenia czasu pracy, zakładania robotniczych związków, prawa do strajku). To wszystko bzdury; wszystko załatwi rewolucja wywołana przez spiskowców, a następnie dyktatura sprawowana przez nich w imieniu ludu, wprowadzająca równość i powszechne szczęście. Blanqui „jest właściwym twórcą - zauważa Kołakowski - idei (choć nie słowa) dyktatury proletariatu sprawowanej w imieniu proletariatu przez zorganizowaną mniejszość"8. Rewolucyjni spiskowcy służą więc ludowi i zarazem manipulują ludem, w imię jego dobra. Są niczym rodzice wobec dzieci.

Ów paternalistyczny stosunek do ludu - tym razem rosyjskiego pojawia się również w doktrynie Tkaczowa, który dąży do rewolucji

7 L. Kołakowski, Główne nurty marksizmu, cz. 1: Powstanie, Poznań 2000, s. 257.

8 L. Kołakowski, Główne nurty marksizmu, dz. cyt., s. 257. 
w Rosji wznieconej i kierowanej - jak u Babeufa i Blanquiego - przez zakonspirowaną organizację inteligenckich spiskowców. W polemicznym liście otwartym do Fryderyka Engelsa, z roku 1874, podaje uzasadnienie takiego stanowiska (Engels krytykował skłonność rosyjskich socjalistów do działalności spiskowej jako przejaw infantylizmu; zabawę w konspirację). Tkaczow powiada, że Engels nie pojmuje realiów rosyjskich oraz twierdzi - z niezwykłą zresztą przenikliwością - że rewolucję komunistyczną łatwiej będzie wywołać w Rosji niż na Zachodzie. Warto przytoczyć jego argumenty.

Specyfika Rosji powoduje, że metody walki socjalistów na Zachodzie nie mogą być tam stosowane. I wylicza: w Rosji nie ma prawie miejskiego proletariatu, dominującym żywiołem są niepiśmienni chłopi, nie ma wolnej prasy, nie ma instytucji przedstawicielskich; co więcej, nawet bezpośrednie legalne oddziaływanie na lud nie może się powieść, albowiem na mocy „ukazu” rządowego każda nieuzasadniona próba zbliżenia się wykształconych do ludu jest traktowana jako przestępstwo ${ }^{9}$. A jednak zwycięstwo „rewolucji socjalnej” w Rosji jest - powtórzmy bardziej prawdopodobne niż na Zachodzie. Dlaczego? Nie ma w Rosji proletariatu miejskiego, ale nie ma też klasy średniej, stabilizatora, który utrwala status quo. Jest tylko „despotyczna władza” i „cierpiący lud”. Lud jest zaś przywiązany do gminnego, wspólnego korzystania z ziemi; własność prywatna jest mu nieznana; jest więc zwolennikiem „kolektywnej własności”, a przeto „komunistą z instynktu, z tradycji”. „Z tego wynika w sposób jednoznaczny, że lud nasz mimo swej ciemnoty jest bliżej socjalizmu niż ludy Europy zachodniej"10. Rosyjski lud przyzwyczaił się do niewoli i uległości, ale nie jest zadowolony ze swego losu. W Rosji wybuchają więc nieustannie - choć przestrzennie odosobnione - bunty i protesty, nawet powstawanie sekt religijnych jest tego przejawem. Informacje o tych buntach są jednak przez carskie władze skrzętnie

9 Chodzi zapewne o zarządzenia ministra oświaty - znanego $\mathrm{z}$ antyliberalnych poglądów Dymitra Tołstoja.

10 P. N. Tkaczow, List otwarty do Pana Fryderyka Engelsa, autora artykułów „Literatura emigracyjna” w nrach 117 i 118 czasopisma „Volksstaat”, rok 1874, w: Filozofia społeczna narodnictwa rosyjskiego. Wybór pism, t. 2, red. A. Walicki, Warszawa 1965, s. 500. 
ukrywane. „Lud uważa swą sytuację za niemożliwą do zniesienia... I dlatego lud rosyjski można nazwać instynktownym rewolucjonistą, mimo jego pozornego otępienia" "11. Co więcej, państwo rosyjskie tylko z daleka robi wrażenie potęgi; jest to jednak siła pozorna; nie posiada korzeni w życiu gospodarczym i nie reprezentuje żadnej klasy. Tkaczow puentuje (a brzmi to niczym proroctwo): „Potrzeba bardzo niewiele - dwóch lub trzech klęsk wojennych, jednoczesnego powstania chłopów w kilku guberniach, otwartego powstania w stolicy w czasie pokoju, a ów urok... momentalnie pryśnie i rząd pozostanie osamotniony, opuszczony przez wszystkich"12. A zatem, mimo że rewolucyjni konspiratorzy w Rosji są nieliczni, są w lepszej sytuacji niż liczni i legalnie działający zachodni socjaliści ${ }^{13}$. Z czasem Tkaczow radykalizuje swoje poglądy, akcentując coraz bardziej rolę spiskowców jako spiritus movens rewolucji i centralizacji władzy po rewolucji; po przejęciu władzy zwycięscy spiskowcy powinni natychmiast przystąpić do tworzenia państwowo-biurokratycznego aparatu przymusu, który „toporem i knutem” będzie wprowadzał komunizm. Nawoływał też do wzniecenia rewolucji natychmiast, a nie do czekania na dopełnienie się jakichś procesów historycznych; przeciwnie, dopełnienie się procesów historycznych może doprowadzić do tego, że Rosja wstąpi na ścieżkę kapitalistycznego rozwoju i wtedy zrobienie rewolucji będzie równie trudne jak w Europie Zachodniej ${ }^{14}$.

11 P. N. Tkaczow, List otwarty do Pana Fryderyka Engelsa..., dz. cyt., s. 501.

12 P. N. Tkaczow, List otwarty do Pana Fryderyka Engelsa..., dz. cyt., s. 502.

13 Co ciekawe, bardzo podobną diagnozę sytuacji przedstawił tuż przed wybuchem wojny światowej w swoim memoriale dla cara Mikołaja II, znajdujący się po przeciwnej niż Tkaczow stronie ideowej barykady, były minister spraw wewnętrznych i policji, konserwatysta Piotr Durnowo. Trafnie przewidział układ sił w wojnie i ostrzegał cara, że jeśli wojna pójdzie źle, „nie da się uniknąć rewolucji społecznej w skrajnej formie" (za: N. Davies, Europa, tłum. E. Tabakowska, Kraków 1998, s. 951). Durnowo umiera na apopleksję w 1915 roku, kiedy wojska carskie doznają rozlicznych klęsk na frontach.

14 „Przekonanie o możliwości ominięcia kapitalizmu - pisze Antoni Kamiński - oparł Tkaczow na swoistej interpretacji «ekonomicznego materializmu», znanego mu z prac Marksa i Spencera. Ścisły determinizm próbował pogodzić ze skrajnym woluntaryzmem, teorię logicznego i stopniowego rozwoju historycznego - z uzasadnianiem możliwości dokonywania historycznych skoków. Uważał, że te ostatnie są możliwe w rzadkich momentach historii, gdy skończył się cykl rozwojowy jednej «zasady ekonomicznej» i nie zaczął się jeszcze cykl «zasady» logicznie następnej. W takim 
Zaryzykowałbym tezę, że Lenin był bardziej spadkobiercą Blanquiego i Tkaczowa niż - zdecydowanie częściej przez niego cytowanego - Marksa. Mieńszewicy zarzucali Leninowi (nie bez racji) blankizm, co oznaczało - w owym sekciarskim żargonie - woluntaryzm. Woluntaryzm zaś oznaczał, że ani nie próbował reformować kapitalizmu w duchu lewicowym, ani nie czekał na komunizm jako na dopełnienie się konieczności historycznej, ale próbował go arbitralną decyzją i rewolucyjnym czynem wprowadzić.

Można też odnieść wrażenie, że za najgroźniejszych wrogów Lenin uznawał - i tam kierował swoje główne ostrze polemiczne - nie liberałów, kapitalistów oraz religię (tu zło było oczywiste), ale właśnie owych umiarkowanych socjalistów, odrzucających przemoc i rewolucję; dążących przeto do „socjalizacji” ustroju na gruncie demokratycznym i z użyciem legalnych środków (w gronie tym znajdowali się zwolennicy Bernsteina, Kautsky'ego oraz przeróżni socjaldemokraci). Zarzucał im tchórzostwo, oportunizm oraz odejście od marksizmu, czyli „rewizjonizm". Odwoływał się między innymi do poglądów Marksa związanych $\mathrm{z}$ analizą przebiegu i upadku Komuny Paryskiej. Marks konkludował: „następna próba rewolucji francuskiej polegać ma nie jak dotychczas na przekazaniu biurokratyczno-militarnej machiny z jednych rąk w drugie, lecz na zdruzgotaniu jej” ${ }^{15}$. „Nic z pism Marksa - zauważa Richard Pipes - o strategii i taktyce rewolucji nie wyryło się trwalej w umyśle

momencie można po prostu zastąpić ją inną, całkowicie nową... W myśli Tkaczowa rewolucja sprowadzała się do umiejętnego wykorzystania sprzyjającego zbiegu okoliczności. Można powiedzieć, że była to teoria «sytuacjonistyczna», ignorująca obiektywne uwarunkowania o charakterze ekonomiczno-politycznym” (A. A. Kamiński, Tkaczow a Bakunin, „Nauki Humanistyczne” (Wrocław) 2008 $\mathrm{nr}$ 12, s. 39-40). Nie jest to zresztą pogląd odosobniony. Zdaniem Bierdiajewa Tkaczow „bardziej niż ktokolwiek inny powinien być uznany za poprzednika Lenina" (M. Bierdiajew, Źródła i sens komunizmu rosyjskiego, tłum. H. Paprocki, Kęty 2005, s. 52). Również przedstawiciele tak zwanej amerykańskiej szkoły interpretacji Lenina traktują Tkaczowa jako jego głównego ideowego poprzednika. Por. A. L. Weeks, The First Russian Bolshevik: A Political Biography of Peter Tkachev, New York 1968, passim.

15 Cyt. za W. Lenin, Państwo a rewolucja, w: Dzieła wszystkie, t. 33, tłum. przekład zbiorowy, Warszawa 1957, s. 26. 
Lenina" ${ }^{16}$. W przededniu bolszewickiego zamachu stanu - ukrywając się w Finlandii - pisze najważniejszą bodaj swoją pracę: Państwo a rewolucja. Był to „traktat nihilistyczny, w którym Lenin dowodzi, że rewolucja musi wyrwać z korzeniami i zniszczyć wszystkie instytucje «burżuazyjne»"17. Określenie „brutalna rewolucja” (czy też - w innym tłumaczeniu - „gwałtowna rewolucja”) pojawia się w tej pracy tak często, że można je uznać za „słowo kluczowe”.

\section{Rewolucja rosyjska}

Rewolucja październikowa miała dwóch głównych przywódców Lenina i Trockiego. Trocki był po stronie praktyki, działania, jej militarnej strony. Lenin bardziej po stronie koncepcji i administrowania. W interesującej nas tu kwestii Lenin wydaje się ważniejszy.

Chciałbym zwrócić uwagę na trzy sprawy. Po pierwsze: Lenin nie popełnił jednego z głównych błędów Robespierre’a (który przyczynił się do jego upadku i załamania się egalitarystycznej tendencji w rewolucji francuskiej). Zadbał mianowicie o stworzenie silnej i bezwzględnie oddanej „gwardii przybocznej”, złożonej w znacznej mierze - jak w schemacie Platona - z "najemników” z innej krainy (były nią oddziały „strzelców łotewskich”, zwanych „pretorianami Lenina”). Stworzył następnie gwardię ogólnokrajową, słynną Czeka, będącą głównym narzędziem „,czerwonego terroru” (postawioną ponad prawem w imię zasady, że cel - komunizm - uzasadnia dowolne środki: rozstrzeliwanie bez sądu, trzyosobowe trybunały rewolucyjne, tortury, obozy koncentracyjne). Rzec można, że - jak każdy tyran - doceniał znaczenie „nagiej siły", bezpośredniej przemocy. Nic dziwnego, że uznał budowę aparatu bezpieczeństwa - bolszewickiej monstrualnej ochrany - za kluczowe dla utrzymania władzy przedsięwzięcie. Podobnie jak Rousseau sądził, że trzeba zmusić lud do wolności (komunistycznej) oraz podobnie jak

17 R. Pipes, Rewolucja rosyjska, dz. cyt., s. 492. 
Robespierre, że cnota bez terroru jest bezsilna; przy czym - powtórzmy dużo lepiej niż ten ostatni zadbał o instytucje i narzędzia terroru.

Po drugie: konsekwentnie realizował ten punkt programu Blanquiego, wedle którego konspiratorzy - uformowani niczym oddział wojskowy, ślepo posłuszni wyższym w hierarchii - po zwycięskiej rewolucji nie przekazują władzy ludowi, ale rządzą sami.

Po trzecie: rewolucję bolszewicką poprzedziła, a następnie jej towarzyszyła, wielka akcja propagandowa (nadzorowana przez Lenina), której główny przekaz brzmiał: „odbierzemy bogatym i przekażemy biednym". Propaganda bolszewicka zapowiadała zatem gigantyczny - wielopoziomowy i wielotorowy - transfer socjalny od bogatych do biednych w imię równości i sprawiedliwości społecznej. Bolszewicy obiecywali, że ziemię odbiorą obszarnikom i oddadzą chłopom („ziemia chłopom"), fabryki zabiorą kapitalistom i oddadzą robotnikom, a władzę również zabiorą bogaczom i oddadzą ludowi (władza w ręce „rad”); a jedynie wojnę pozostawią bogaczom, a biednym podarują pokój („pokój chatom”).

Była to jednak manipulacja, celowe oszustwo (przypominające w intencjach platońskie „zdrowe kłamstwo”). Lenin zbudował potiomkinowską fasadę ludowładztwa, za którą znajdowały się realne rządy zawodowych rewolucjonistów. Co więcej, w rzeczywistości tylko malutka część dóbr bogaczy trafiła w ręce biednych (w przypadku ziemi przyznanej chłopom, a dokładnie wspólnotom chłopskim, na jakiś czas, albowiem prawdziwy program Lenina i bolszewików przewidywał nacjonalizację ziemi, co zostało przeprowadzone przez jego następcę). Ale, na przykład, do wielopokojowych mieszkań zamożnych mieszczan dokwaterowano „na dobre” (a raczej „na złe”) proletariuszy, pałace zamieniono na gmachy rządowe, muzea, sierocińce itp. A jedyny w Rosji zamek, czyli Kreml, na centralną warownię nowej władzy. Również tylko niewielką część - skonfiskowanego pod pozorem walki z głodem - ruchomego majątku prawosławnej cerkwi przeznaczono na pomoc głodującym (do głodu przyczyniła się zresztą obłędna - zwana „komunizmem wojennym" - polityka gospodarcza, a konkretnie rekwizycje zboża, również ziarna siewnego). 
„Pokój chatom”, to - z kolei - wojna domowa, której liczba ofiar (jeśli uwzględnić głód na Powołżu) była zbliżona do liczby poległych na wszystkich frontach pierwszej wojny światowej.

Gdzie więc trafia większa część dóbr przejętych przez bolszewików, zarekwirowanych, zrabowanych dotychczasowym właścicielom (nacjonalizacja fabryk, kolei, banków i wszystkich umieszczonych w nich depozytów, wreszcie majątku cerkwi prawosławnej oraz rodziny carskiej), owa - mówiąc metaforycznie - „góra złota"? Otóż - posłużmy się jeszcze raz cytatem z Platona - „zabierają tym,którzy mają majątek, dzielą między lud, a najwięcej zachowują dla siebie". Zachowują dla siebie i przeznaczają na budowę i utrzymanie nowego aparatu władzy, a szczególnie jego siłowych odgałęzień - politycznej policji oraz armii (czerwonej). Owo wielkie źródło bogactwa pomogło Leninowi i Trockiemu wygrać „wojnę domową" z białymi, poskromić rozliczne bunty chłopskie i strajki robotnicze, pokonać zbuntowanych marynarzy w Kronsztadzie, odzyskać większość - obcych narodowo - terytoriów należących do carskiej Rosji, które przez moment wybiły się na niepodległość. No i wreszcie temat szczególnie nas, Polaków, interesujący - zmierzyć się z najsilniejszym z ujarzmionych przez carat narodów, z nadzieją na „eksport rewolucji” do Niemiec, a następnie, zgodnie $\mathrm{z}$ „naukowym proroctwem” Marksa, na cały glob.

To jednak się nie udało. Polska się obroniła. Ale tylko za pierwszym razem. Ten sam tyrański aparat państwowy i militarny - wyrosły między innymi na rabunku bogactw carskiej Rosji - po dwudziestu pięciu latach podbił nie tylko Polskę, ale też całą Europę Środkowo-Wschodnią, zerkając łapczywie na jej resztę i na inne kontynenty.

\section{Zakończenie}

$\mathrm{W}$ teorii, $\mathrm{w}$ rozlicznych egalitarystycznych utopiach, sprawa jest jasna, hierarchia - cel i środek - oczywista; centralizacja władzy służy równości, terror służy cnocie. W praktyce rewolucyjnej rzecz się komplikuje; na poziomie ideologii i propagandy sprawa wygląda jak 
w utopiach, w rzeczywistości jednak - wraz z rośnięciem rewolucyjnej fali i jej radykalizacją - coraz większy nacisk kładziony jest na utrzymanie i wzmocnienie władzy, na centralizację i terror. Równość i cnota stają się hasłem coraz bardziej pozbawionym treści, listkiem figowym nakładanym na zbrodnie władzy. Przywódcy rewolucji, mający coraz więcej krwi niewinnych na rękach - jak w schemacie Platona - „przekraczają Rubikon” i nie mają już gdzie się cofnąć ${ }^{18}$. Ideowi egalitaryści przekształcają się w praktyków-tyranów; co gorsza, ich szeregi zasilane są przez cynicznych i bezwzględnych karierowiczów, traktujących ideologię „równości” całkiem instrumentalnie. W przypadku rewolucji rosyjskiej było to szczególnie widoczne; heroiczni ideowcy z otoczenia Lenina zostają wymienieni - z pomocą kata - na biurokrację stalinowską.

Na koniec kilka uwag ogólnych. Pojęcia „równości” i „sprawiedliwości” są ze sobą powiązane; istnieją jednakże - co najmniej - trzy różne rozumienia równości, a przeto i trzy różne rozumienia sprawiedliwości.

W pierwszym rozumieniu chodzi o „równe prawa dla równych”; o właściwą hierarchię i proporcję. Zakłada się bowiem, że ludzie różnią się jakościowo; są zatem z natury nierówni ( $\mathrm{z}$ urodzenia lub ze względu na „odwieczną” pozycję społeczną): szlachetni i mniej szlachetni, dostojni i mniej dostojni, wyżsi i niżsi. Prawa powinny być zatem odmienne i proporcjonalne dla każdej z tych grup (stanów, kast). Zacytujmy polskie przysłowie: „Co wolno wojewodzie, to nie tobie smrodzie”. I to jest właśnie sprawiedliwe. Taka koncepcja sprawiedliwości - którą można by nazwać arystokratyczną - dominuje w antyku i w średniowieczu. Świetnie oddaje ją etyka Arystotelesa.

18 Platon daje w ósmej księdze Państwa doskonały zarys psychologii tyrana. Im więcej tyran morduje, tym bardziej czuje się zagrożony, im bardziej czuje się zagrożony, tym więcej - w imię bezpieczeństwa - morduje. Rozsmakowuje się przeto w przelewaniu krwi niewinnej, w terrorze i zbrodni; nie tylko jednak dlatego, że „wchodzi mu to w krew” (staje się niejako wilkiem), ale też dlatego, że służy to jego poczuciu bezpieczeństwa i ufności w życie. Czyli że - kiedy giną słabi i niewinni ma wrażenie, że wszystko jest w porządku, że wszystko jest na swoim miejscu; niczym w przyrodzie. Takie jest bowiem prawo natury, że słabsi giną. Stalin, kiedy widzi, że miliony idą na śmierć, gładzi wąsy, bo czuje się bardziej bezpieczny. 
W drugim rozumieniu chodzi o „równe prawo dla wszystkich”. Wszyscy powinni mieć równe uprawnienia i obowiązki; wiąże się to z koncepcją przyrodzonej równości ludzi (może mieć ona tło chrześcijańskie albo wiązać się z koncepcjami umowy społecznej, do której przystępują wolne i równe podmioty). Ludzie są równi z natury, ale nie identyczni, a zatem równe prawo (identyczne reguły) prowadzi do empirycznej nierówności i to jest sprawiedliwe. Taką koncepcję sprawiedliwości można nazwać liberalną. Jest ona zresztą jednym ze składników fundamentu liberalnej demokracji. A jej ekonomicznym zwieńczeniem jest podatek liniowy.

W trzecim zaś chodzi o to, aby było „po równo dla wszystkich”. Ludzie nie tylko są równi z natury, ale też - w istocie - identyczni; empiryczne różnice nie są niczyją zasługą, ale efektem przypadku: dziedziczności lub (zazwyczaj złych) stosunków społecznych. „Wszyscy mają takie same żołądki" - głosi popularne uzasadnienie takiego podejścia. Wprowadzenie sprawiedliwego, czyli „zrównującego”, ustroju powinno doprowadzić do tego, że ludzie staną się empirycznie równi; identyczni co do zdolności, inteligencji, pracowitości, siły, wyglądu (wątek częsty w egalitarystycznych utopiach ${ }^{19}$ ), a nade wszystko równi w korzystaniu $\mathrm{z}$ dóbr materialnych („każdemu tyle samo”). To jednak wymaga wprowadzenia właśnie nierównych praw, praw „zrównujących”, różnych kryteriów; niżsi i biedniejsi (pokrzywdzeni przez los) powinni być traktowani łagodniej, wyżsi i bogatsi surowiej (jest to niejako rewers pierwszej koncepcji sprawiedliwości). Bogaczowi odbiera się dużo lub wszystko, biednemu mało lub nic. Synowi analfabety za rozwiązanie trzech zadań stawia się piątkę, synowi „inteligenta” za rozwiązanie pięciu trójkę i tylko ten pierwszy trafia na studia. W sferze ekonomicznej jej zwieńczeniem jest podatek progresywny; im wyższa progresja, tym bliżej ideału tak pojętej równości i sprawiedliwości. Taka koncepcja - można ją nazwać sprawiedliwością egalitarystyczną, „zrównującą” - panowała w demokracjach ludowych.

19 Najdalej bodaj posunięty w niezwykłej utopii Dom Deschampsa, w której wszystkie kobiety i wszyscy mężczyźni są jak jedna kobieta i jeden mężczyzna (niczym „owady społeczne”). Por. D. L. M. Deschamps, Prawdziwy system, czyli rozwiązanie zagadki metafizyki i moralności, tłum. B. Baczko, E. Bąkowska, Warszawa 1967. 
Pojawia się, rzecz jasna, pytanie, kto ma owo nierówne prawo równo rozdzielać, kto ma ową nierówną miarą sterować? W przypadku równej miary nie potrzebna jest ingerencja mierniczego; decyduje prawo. W przypadku nierównej miary potrzebny jest mierniczy, postawiony ponad prawem, który dokonuje subiektywnych regulacji i wyrównań. Jest to ścieżka prowadząca nie do władzy prawa, ale to władzy arbitralnej, na której końcu znajduje się dyktatura, tyrania i terror.

No właśnie: terror w imię równości i identyczności, a nie wolności. „Doniosłość ruchu babuwistów polega też na tym - pisze Kołakowski - że po raz pierwszy doszła w nim do głosu świadomość konfliktu, jaki zachodził między dwoma naczelnymi hasłami rewolucji: wolnością i równością. Wolność oznaczała bowiem nie tylko prawo zrzeszania się i zniesienia prawnych różnic między stanami, ale także prawo każdego do nieskrępowanej aktywności ekonomicznej i do zabiegania o swoją własność; tym samym wolność oznaczała nierówność, wyzysk i nędzę"20. Wolność, „wolną rękę” będzie można zostawić ludziom dopiero wtedy, kiedy oduczą się już działać na „własną rękę”, kiedy wypleni się do cna egoizm. „Dlatego też - powiada Tkaczow - najbardziej istotna, najbardziej charakterystyczna cecha przyszłego społeczeństwa powinna być określona nie słowem «anarchia», lecz słowem - "równość»"21. I dowodzi, że najpierw trzeba - posługując się przemocą państwową i terrorem - ludzi zrównać. A kiedy już będą prawdziwie równi (czyli prawie identyczni), to spontanicznie zrodzi się braterstwo; i wtedy dopiero będzie mogło zniknąć państwo. „Tam, gdzie jest braterstwo, tam jest równość, tam, gdzie jest równość - tam jest i bezrząd, i wolność"22. Tkaczow, a później Lenin, nie mieli więc złudzeń i uważali, że bez terroru nie da zaprowadzić identyczności ludzi i nie da się jej utrzymać, aż do czasu, aż „wejdzie ona im w krew”. A zatem rezygnację z terroru trzeba

21 P. N. Tkaczow, Program czasopisma „Nabat”, w: Filozofia społeczna narodnictwa rosyjskiego. Wybór pism, t. 2, s. 93.

22 P. N. Tkaczow, Program czasopisma „Nabat”, dz. cyt., s. 94. 
odłożyć „na jutro”. I tu się mylili; należałoby bowiem powiedzieć „na zawsze jutro".

Wśród egalitarystycznych spiskowców można zatem odnotować narastającą świadomość tego, że aby doprowadzić do równości, trzeba wprowadzić tyranię. Albowiem zero wolności współgra z maksimum równości (maksimum równości zaś to tak zwany „komunizm koszarowy”; sądzę zresztą, że innego - w dużej skali społecznej - zrobić się nie da). Przy czym owi zwolennicy równości nie chcą zrezygnować z pięknie brzmiącego i budzącego pozytywne skojarzenia słowa „wolność”. Albo zatem odkładają ją „na potem”, albo skrywają anihilację wolności i ją wychwalają: „Ja drugoj takoj strany nie znaju, gdie tak wolno dyszyt czełowiek" śpiewała Lubow Orłowa w propagandowym filmie Cyrk z roku 1936, w epicentrum stalinowskiego terroru.

Liberalna demokracja wyklucza równość w korzystaniu $\mathrm{z}$ dóbr materialnych. Taką równość (tytułową „sprawiedliwość społeczną”) może zaprowadzić tylko tyrania mniejszości sprawowana w imieniu ludu, a w istocie - jak zauważył Platon dwadzieścia cztery wieki temu - przeważnie we własnym imieniu. Wielokrotnie w tym tekście odwoływałem się do owego spostrzeżenia Platona. Nasuwa się następująca konkluzja: nihil novi sub sole.

\section{Bibliografia}

Bierdiajew N., Źródła i sens komunizmu rosyjskiego, tłum. H. Paprocki, Kęty 2005.

Buonarroti P., Sprzysiężenie równych, tłum. A. Jeżewski, Warszawa 1952.

Davies N., Europa, tłum. E. Tabakowska, Kraków 1998.

Deschamps D. L. M., Prawdziwy system, czyli rozwiazanie zagadki metafizyki i moralności, tłum. B. Baczko, E. Bąkowska, Warszawa 1967.

Kamiński A. A., Tkaczow a Bakunin, „Nauki Humanistyczne” (Wrocław) 2008 nr 12, s. 31-52.

Kołakowski L., Główne nurty marksizmu, cz. 1: Powstanie, Poznań 2000.

Lenin W., Państwo a rewolucja, w: Dzieła wszystkie, t. 33, tłum. przekład zbiorowy, Warszawa 1957.

Pipes R., Rewolucja rosyjska, tłum. T. Szafar, Warszawa 2014. 
Platon, Państwo, tłum. W. Witwicki, Warszawa 1958.

Tkaczow P. N., List otwarty do Pana Fryderyka Engelsa, autora artykułów „Literatura emigracyjna” w nrach 117 i 118 czasopisma „Volksstaat”, rok 1874, w: Filozofia społeczna narodnictwa rosyjskiego. Wybór pism, t. 2, red. A. Walicki, Warszawa 1965, s. 496-512. Tkaczow P. N., Program czasopisma „Nabat”, w: Filozofia społeczna narodnictwa rosyjskiego. Wybór pism, t. 2, red. A. Walicki, Warszawa 1965, s. 86-102.

Weeks A. L., The First Russian Bolshevik: A Political Biography of Peter Tkachev, New York 1968.

\section{Abstrakt}

\section{Hasło sprawiedliwości społecznej jako wstęp do tyranii}

Hasło sprawiedliwości społecznej różnie w historii było rozumiane; bywało podstawą przemian - w szerokim sensie tego słowa - demokratycznych, ale też okazywało się propagandowym „chwytem” i wstępem do tyranii. Platon był bodaj pierwszy, który w swojej opisowej koncepcji ewolucji ustrojów zwrócił uwagę na to, że demokracja - kiedy wątek „redystrybucji dóbr” w imię egalitaryzmu i zrównania wychodzi na plan pierwszy - niejako spontanicznie zamienia się w tyranię. Próbował temu zapobiec Arystoteles w swojej koncepcji politei. Chciałbym się zastanowić (w ogromnym, rzecz jasna, skrócie), na ile te koncepcje „sprawdzały się w historii” i są obecnie aktualne. Chciałbym też - na zakończenie - zaprezentować trzy modele „sprawiedliwości społecznej”: hierarchiczny (starożytny), oparty na równym kryterium (nowożytny, liberalny) oraz egalitarystyczny (utopijny, zrównujący), będący ideologią prowadzącą do scentralizowanej, arbitralnej, a nawet tyrańskiej władzy.

\section{Słowa kluczowe}

Platon, utopia, rewolucja, równość, terror 


\section{Abstract}

\section{The slogan of social justice as an introduction to tyranny}

The slogan of "social justice" was variously understood in history; it was the basis of changes - in the broad sense of the word - democratic, but it also turned out to be a propaganda "catch" and an introduction to tyranny. Plato was perhaps the first who pointed out that democracy - when the theme of "redistribution of goods" and egalitarianism comes to the forefront - spontaneously turns into tyranny. Aristotle, in his policy concept (politeia), tried to prevent it. I would like to consider (in a nutshell) how these concepts "worked in history" and are currently valid. Finally, I would like to present three models of "social justice": hierarchical (ancient), based on an equal criterion (modern, liberal) and egalitarian (utopian, leveling), which is an ideology leading to centralized, arbitrary and even tyrannical power.

\section{Keywords}

Plato, utopia, revolution, equality, terror 